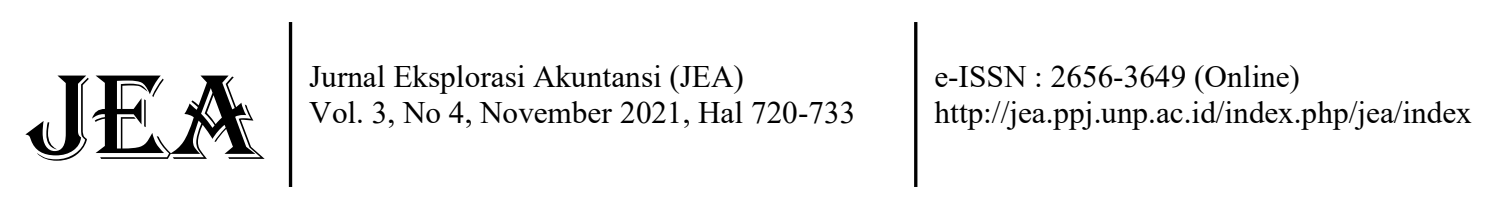

\title{
Pengaruh Penerapan Good Corporate Governance dan Struktur Kepemilikan terhadap Kinerja Perusahaan: Studi Empiris pada Perusahaan Non Keuangan
}

\author{
Ninda Novita Yoza ${ }^{1 *}$, Efrizal Syofyan ${ }^{2}$ \\ ${ }^{1,2}$ Fakultas Ekonomi, Universitas Negeri Padang \\ *Korespondensi: nindanovitayoza@gmail.com
}

\begin{abstract}
This study aims to determine the effect of implementing good corporate governance and ownership structure on company profitability. The independent variables are the board of commissioners, the board of directors, the audit committee, managerial ownership, and institutional ownership. While the dependent variable is the company's profitability. The sample used is non-financial companies in the infrastructure, utilities, and transportation sectors listed on the Indonesia Stock Exchange in 2017-2019. The statistical method used is multiple linear regression analysis. The results showed that the board of commissioners had a negative and insignificant effect on the company's profitability, the board of directors and the audit committee had a positive and significant effect on the company's profitability, managerial ownership and institutional ownership had a positive and insignificant effect on the company's profitability.
\end{abstract}

Keywords : Company Ownership Structure; Good Corporate Governance; Profitability.

How to cite (APA $6^{\text {th }}$ style)

Yoza, N.N \& Syofyan, E. (2021). Pengaruh Penerapan Good Corporate Governance dan Struktur Kepemilikan terhadap Kinerja Perusahaan: Studi Empiris pada Perusahaan Non Keuangan. Jurnal Eksplorasi Akuntansi (JEA), 3 (4), 720-733.

\section{PENDAHULUAN}

Kinerja perusahaan adalah kemampuan perusahaan dalam meraih tujuannya melalui pemakaian sumber daya secara efektif dan efisien serta menggambarkan hasil pencapaian dari suatu perusahaan (Muhammad, 2008). Kinerja perusahaan dapat diukur menggunakan rasio profitabilitas. Profitabilitas perusahaan merupakan kemampuan suatu perusahaan dalam memperoleh laba selama periode tertentu dan juga merupakan rasio untuk menilai kemampuan perusahaan dalam mendapatkan keuntungan. Profitabilitas merupakan kemampuan perusahaan untuk menghasilkan laba dengan menggunakan sumber - sumber yang dimiliki perusahaan, seperti asset, modal, atau penjualan (Sudana, 2011).

Suatu perusahaan menginginkan profitabilitasnya meningkat setiap tahun. Hal ini dikarenakan rasio profitabilitas biasanya dijadikan bahan pertimbangan investor dalam menanamkan sahamnya disuatu perusahaan. Apabila suatu perusahaan mempunyai tingkat profitabilitas yang tinggi terhadap pengembalian saham, maka seorang investor akan memilih perusahaan tersebut untuk menanamkan sahamnya. Selain itu, menurut Kasmir (2014) rasio profitabilitas itu penting bagi perusahaan karena dengan mengetahui rasio profitabilitas tersebut perusahaan dapat : mengetahui besarnya tingkat laba yang diperoleh dalam suatu 
periode, mengetahui posisi laba perusahaan tahun sebelumnya dengan tahun sekarang, mengetahui perkembangan laba dari waktu ke waktu, mengetahui besarnya laba bersih sesudah pajak dengan modal sendiri, serta mengetahui produktivitas dari seluruh dana perusahaan yang digunakan baik modal pinjaman maupun modal sendiri.

Peneliti memilih perusahaan non keuangan sektor infrastruktur, utilitas, dan transportasi sebagai objek penelitian karena jika dilihat dari perhatian pemerintah terhadap penyediaan infrastruktur sangatlah minim apalagi di daerah luar jawa. Hal itu dikarenakan pemerintah lebih fokus pada hal-hal seperti menjaga stabilitas nilai tukar rupiah dan perkembangan ekonomi, menangulangi hutang luar negeri, dan menstabilkan situasi politik dan ekonomi. Selain itu perusahaan ini merupakan sektor yang perkembangannya cukup pesat, seperti yang dikatakan Rini Soemarmo (Menteri BUMN) pada tahun 2019 bahwa pembangunan infrastruktur, utilitas, dan transportasi merupakan aspek yang sangat penting dalam mempercepat proses pembangunan nasional (Saeno, 2019). Infrastruktur, utilitas dan transportasi memegang peranan yang sangat penting dalam pembangunan ekonomi Indonesia. Laju pertumbuhan ekonomi nasional tidak terpisahkan dari ketersediaan infrastruktur, seperti sarana transportasi, telekomunikasi, sistem penyediaan tenaga listrik, sistem penyediaan air bersih, irigasi, dan sanitasi.

Pembangunan infrastruktur di Indonesia terjadi peningkatan APBN dari tahun 2014 sampai 2016. Namun, untuk target pembangunan tahun 2019 pemerintah pusat dan daerah hanya dapat memberikan kontribusi sebesar $41 \%$ untuk pembiayaan, sementara perusahaanperusahaan milik negara (BUMN) hanya dapat memberikan kontribusi hingga $22 \%$ sehingga $37 \%$ dari dana yang dibutuhkan harus berasal dari sektor swasta (www.bappenas.go.id). Selain itu, sektor infrastruktur, utilitas, dan transportasi juga merupakan sektor yang padat modal dan menuntut pendanaan jangka panjang, sehingga investor masih dibayangi akan risiko yang tinggi ketika berinvestasi pada sektor ini. Investor tentunya akan sangat mempertimbangkan potensi keuntungan dan risiko yang didapat ketika hendak berinvestasi. Oleh karena itu, untuk menarik minat investor pengelolaan perusahaan harus dilakukan dengan sebaik mungkin.

Pengelolaan perusahaan yang baik itu dapat dilihat dari kinerja perusahaan yang dapat dinilai dari pertumbuhan laba perusahaan. Perusahaan dengan kinerja yang baik akan tercermin dari pertumbuhan laba yang meningkat, begitu pula sebaliknya. Apabila perusahaan tidak mengelola kinerjanya dengan baik maka pertumbuhan laba perusahaan akan menurun.

Tabel 1

Persentase Pertumbuhan Laba Sektor Infrastruktur, Utilitas, dan Transportasi Tahun 2017-2019

\begin{tabular}{lccc}
\hline \multicolumn{1}{c}{ Sub Sektor } & $\mathbf{2 0 1 7}(\mathbf{\%})$ & $\mathbf{2 0 1 8}(\mathbf{\%})$ & $\mathbf{2 0 1 9}(\%)$ \\
\hline Energi & & & $-1,06$ \\
Jalan Tol, Pelabuhan, Bandara, dan & $-0,05$ & 37,13 & $-0,01$ \\
Sejenisnya & 0,09 & 0,56 & $-0,20$ \\
Telekomunikasi & 0,01 & $-0,10$ & $-0,03$ \\
Transportasi & 0,71 & 0,02 & $-0,01$ \\
Konstruksi non Bangunan & $-0,65$ & $-0,02$ & $-0,262$ \\
Rata-rata & 0,02 & 7,518 & \\
\hline
\end{tabular}

Sumber : data sekunder yang diolah

Berdasarkan Tabel 1 dapat dilihat bahwa perusahaan sektor infrastruktur, utilitas, dan transportasi mengalami pertumbuhan laba yang tidak stabil dan cenderung menurun dari 
tahun 2018 sampai 2019. Pada tahun 2019 rata-rata perusahaan juga mengalami pertumbuhan laba negatif. Data diatas menunjukkan bahwa pertumbuhan laba pada tahun 2017 sebesar 0,02, lalu pada tahun 2018 mengalami kenaikan persentase pertumbuhan laba sebesar 7,518. Namun, pada tahun 2019 perusahaan mengalami penurunan persentase pertumbuhan laba yang cukup drastis yaitu sebesar $-0,262 \%$. Penurunan pertumbuhan laba perusahaan ini dapat mengakibatkan profitabilitas perusahaan menurun. Penurunan pertumbuhan laba dari tahun 2018 sampai tahun 2019 ini bisa membuat investor ragu untuk berinvestasi, apalagi penurunan laba yang cukup signifikan akan membuat investor mempertanyakan apakah masalah yang terjadi pada perusahaan sehingga perusahaan bisa mengalami penurunan laba yang signifikan tersebut.

Kondisi keuangan dari suatu perusahaan salah satunya dapat dilihat dari laba yang dihasilkan oleh perusahaan tersebut. Laba perusahaan dapat diukur menggunakan rasio profitabilitas. Berdasarkan rasio profitabilitas perusahaan dapat dilihat bagaimana perkembangan perusahaan dari tahun ke tahun. Apabila perusahaan yang mempunyai rasio profitabilitas tinggi maka laba yang dihasilkan perusahaan juga tinggi (Priatna, 2016). Suatu perusahaan dapat memperoleh profitabilitas yang baik apabila perusahaan mampu menjaga dan menjalankan tata kelola perusahaannya dengan baik. Peran good corporate governance terhadap profitabilitas ini akan mencerminkan bagaimana hubungan yang akan terjalin dengan investor. Good corporate governance pada penelitian ini diukur menggunakan 3 variabel, yaitu dewan komisaris, dewan direksi, dan komite audit.

Selain good corporate governance, hal yang dapat berpengaruh terhadap profitabilitas perusahaan adalah struktur kepemilikan perusahaan (Sembiring, 2017). Struktur kepemilikan ini merupakan sistem yang mengatur tentang pemisahan antara pemilik perusahaan dan manajer yang mana struktur kepemilikan ini dapat mengurangi adanya konflik antara pemegang saham dan manajemen sehingga komposisi modal antara hutang dan ekuitas dapat tergambarkan secara jelas. Struktur kepemilikan juga merupakan mekanisme dari corporate governance untuk mengurangi konflik antara pihak manajemen dengan pemegang saham. Struktur kepemilikan perusahaan dapat diukur menggunakan kepemilkan manajerial dan kepemilikan institusional.

Penelitian tentang good corporate governance dan struktur kepemilikan terhadap profitabilitas ini menarik diteliti karena variabel ini merupakan hal yang sangat penting dalam mewujudkan peningkatan kinerja perusahaan melalui monitoring kinerja manajemen dan menjamin akuntabilitas manajemen terhadap para pemegang saham. Selain itu, good corporate governance dan struktur kepemilikan merupakan salah satu strategi jangka panjang agar perusahaan tetap berjalan dan beroperasi dengan baik. Penelitian ini juga diharapkan dapat menjadi bahan untuk mempertimbangkan bahwa kekuatan good corporate govenrnace dan struktur kepemilikan akan mempunyai kontribusi yang cukup signifikan atau mempunyai peranan terhadap profitabilitas perusahaan. Selain itu, penelitian ini dapat dijadikan pedoman dan pertimbangan bagi calon investor sebelum melakukan investasi pada perusahaan.

\section{REVIEW LITERATUR DAN HIPOTESIS}

Profitabilitas perusahaan merupakan kemampuan suatu perusahaan dalam memperoleh laba selama periode tertentu dan juga merupakan rasio untuk menilai kemampuan perusahaan dalam mendapatkan keuntungan. Profitabilitas berpengaruh dalam pembuatan keputusan investasi untuk menghasilkan keuntungan suatu perusahaan. Profitabilitas merupakan kemampuan perusahaan untuk menghasilkan laba dengan menggunakan sumber-sumber yang dimiliki perusahaan, seperti asset, modal, atau penjualan (Sudana, 2011).

Menurut Munawir (2004) faktor-faktor yang mempengaruhi profitabilitas perusahaan adalah jenis perusahaan, umur perusahaan, skala perusahaan, harga produksi, hakikat bisnis, 
dan produk yang dihasilkan. Selain itu, menurut Hantono (2018) faktor lain yang mempengaruhi profitabilitas adalah perputaran kas, perputaran piutang, dan likuiditas. Beberapa indikator yang dapat digunakan untuk pengukuran profitabilitas yaitu laba bersih, laba operasi, tingkat pengembalian investasi/asset, dan tingkat pengembalian ekuitas pemilik modal atau perusahaan.

Dalam menganalisis profitabilitas perusahaan, terdapat beberapa jenis rasio profitabilitas yang dapat digunakan, yaitu : Gross Profit Margin, Net Profit Margin, Return on Investment (ROI), Return on Equity (ROE), Return on Sales, Return on Capital Employed, dan Earning Per Share (EPS). Menurut Indonesian Institut of Corporate Governance (IIGC), good corporate governance merupakan serangkaian mekanisme untuk mengarahkan dan mengendalikan suatu perusahaan agar operasional perusahaan berjalan dapat sesuai dengan harapan para pemangku kepentingan (stakeholder). Menurut (Effendi, 2009) good corporate governance adalah suatu sistem pengendalian internal perusahaan yang memiliki tujuan utama mengelola risiko yang signifikan guna memenuhi tujuan bisnisnya melalui pengamanan asset perusahaan dan meningkatkan nilai investasi pemegang saham dalam jangka panjang. Terdapat lima asas dari good corporate governance, yaitu : Transparansi, akuntabilitas, responsibilitas, dan independensi.

Indikator yang dapat digunakan dalam pengukuran good corporate governance terhadap profitabilitas perusahaan yaitu : dewan komisaris, dewan direksi, dan komite audit. Tugas dan tanggung jawab dari dewan komisaris yaitu mengawasi jalannya perusahaan berdasarkan prinsip-prinsip good corporate governance. Meningkatnya profitabilitas perusahaan dapat dilihat dari semakin tingginya ukuran dewan komisaris dalam meningkatkan kinerjanya pada pengawasan suatu perusahaan. Dewan direksi mempunyai tugas dalam menentukan arah kebijakan dan strategi sumber daya perusahaan. Profitabilitas perusahaan akan meningkat apabila jumlah anggota dewan direksi semakin banyak. Semakin banyaknya anggota dewan direksi ini akan menghasilkan banyaknya ahli yang mempunyai kemampuan operasional pada berbagai bidang dan divisi, sehingga perusahaan akan dapat mencapai tujuan dari perusahaan tersebut. Komite audit mempunyai tugas khusus dalam membantu dewan komisaris memastikan bahwa laporan keuangan perusahaan disajikan secara wajar yang sesuai dengan standar dan prinsip akuntansi yang berlaku umum. Anggota komite audit harus memiliki keahlian yang cukup dalam bidang akuntansi dan audit karena komite audit mempunyai tugas dalam melakukan pengawasan yang efektif untuk mengevaluasi isu-isu yang terdapat pada perusahaan. Dengan adanya komite audit yang memiliki keahlian tersebut, maka dapat membantu perusahaan dalam meningkatkan kualitas kinerja dan informasi keuangan yang dapat memperbaiki kondisi keuangan dan meningkatkan profitabilitas perusahaan.

Menurut Sudana (2011) struktur kepemilikan merupakan pemisahan antara pemilik perusahaan dan manajer perusahaan. Indikator yang dapat digunakan dalam struktur kepemilikan perusahaan adalah kepemilikan manajerial dan kepemilikan institusional. Menurut Tjeleni (2013) kepemilikan manajerial merupakan situasi dimana manajer memiliki saham perusahaan atau dengan kata lain manajer tersebut sekaligus sebagai pemegang saham. Hubungan antara kepemilikan manajerial dengan profitabilitas yaitu profitabilitas perusahaan akan meningkat apabila kepemilikan manajerial yang dimiliki oleh suatu perusahaan itu semakin besar, karena manajer akan cenderung bekerja lebih giat untuk kepentingan pemegang saham sehingga dapat meningkatkan profitabilitas perusahaan. Menurut Masdupi (2005) kepemilikan institusional merupakan proporsi saham yang dimiliki institusional pada akhir tahun yang diukur dalam persentase saham yang dimiliki oleh investor institusional dalam suatu perusahaan. Peran kepemilikan institusional yaitu dalam meminimalisasi konflik keagenan yang terjadi antara manajer dan pemegang saham. Hubungan antara kepemilikan 
institusional dengan profitabilitas perusahaan yaitu semakin tinggi tingkat kepemilikan institusional maka akan meningkatkan profitabilitas perusahaan.

\section{Pengaruh Ukuran Dewan Komisaris terhadap Profitabilitas Perusahaan}

Tugas dan tanggung jawab dari dewan komisaris yaitu mengawasi jalannya perusahaan berdasarkan prinsip-prinsip good corporate governance. Dewan komisaris secara tidak langsung berkaitan dengan profitabilitas perusahaan. Apabila dewan komisaris tidak dapat melaksanakan tugas dan tanggung jawabnya dengan baik maka akan mempengaruhi profitabilitas perusahaan. Meningkatnya profitabilitas perusahaan dapat dilihat dari semakin tingginya ukuran dewan komisaris dalam meningkatkan kinerjanya pada pengawasan suatu perusahaan. Berdasarkan uraian diatas, maka hipotesis penelitian adalah sebagai berikut :

H1: Ukuran dewan komisaris berpengaruh positif terhadap profitabilitas perusahaan.

\section{Pengaruh Ukuran Dewan Direksi terhadap Profitabilitas Perusahaan.}

Dewan direksi harus mampu menjalin komunikasi dan koordinasi yang baik dalam melakukan suatu pekerjaan. Jumlah dewan direksi juga perlu diperhitungkan dan logis, karena adanya pengaruh jumlah dewan direksi dengan kecepatan pengambilan keputusan perusahaan. Profitabilitas perusahaan akan meningkat apabila jumlah anggota dewan direksi semakin banyak. Semakin banyaknya anggota dewan direksi ini akan menghasilkan banyaknya ahli yang mempunyai kemampuan operasional pada berbagai bidang dan divisi, sehingga perusahaan akan dapat mencapai tujuan dari perusahaan tersebut. Berdasarkan uraian diatas, hipotesis penelitian berikutnya yaitu :

H2: Ukuran dewan direksi berpengaruh positif terhadap profitabilitas perusahaan.

\section{Pengaruh Ukuran Komite Audit terhadap Profitabilitas Perusahaan.}

Anggota dari komite audit harus memiliki keahlian yang cukup dalam bidang akuntansi dan audit tersebut, karena komite audit mempunyai tugas dalam melakukan pengawasan yang efektif untuk mengevaluasi isu-isu yang terdapat pada perusahaan. Dengan adanya komite audit yang memiliki keahlian tersebut, maka dapat membantu perusahaan dalam meningkatkan kualitas kinerja dan informasi keuangan yang dapat memperbaiki kondisi keuangan dan meningkatkan profitabilitas perusahaan. Berdasarkan uraian diatas, maka hipotesis penelitian berikutnya adalah :

H3: Komite audit berpengaruh positif terhadap profitabilitas perusahaan.

\section{Pengaruh Kepemilikan Manajerial terhadap Profitabilitas Perusahaan.}

Semakin besar saham yang dimiliki oleh manajerial maka dapat memperbaiki dan meningkatkan kinerja perusahaan, selain itu juga dapat meningkatkan harga saham dan kinerja keuangan perusahaan. Profitabilitas perusahaan akan meningkat apabila kepemilikan manajerial yang dimiliki oleh suatu perusahaan itu semakin besar, karena manajer akan cenderung bekerja lebih giat untuk kepentingan pemegang saham sehingga dapat meningkatkan profitabilitas perusahaan. Berdasarkan uraian diatas maka hipotesis untuk penelitian berikutnya yaitu:

H4: Kepemilikan manajerial berpengaruh positif terhadap profitabilitas perusahaan.

\section{Pengaruh Kepemilikan Institusional terhadap Profitabilitas Perusahaan.}

Kepemilikan instistusional mempunyai peranan penting dalam meminimalisir konflik keagenan yang dapat terjadi antara manajer dan pemegang saham. Investor institusional terlibat dalam pengambilan keputusan perusahaan. Semakin besar kepemilikan institusional maka semakin besar pula kekuatan dan dorongan suara institusi tersebut dalam mengawasi pihak manajemen. Hal ini akan memberikan dorongan untuk meningkatkan kinerja perusahaan. Hubungan kepemilikan institusional dengan profitabilitas perusahaan yaitu 
semakin tinggi tingkat kepemilikan institusional maka akan meningkatkan profitabilitas perusahaan. Berdasarkan penjelasan diatas, maka hipotesis penelitian berikutnya adalah :

H5: Kepemilikan institusional berpengaruh positif terhadap profitabilitas perusahaan.

\section{METODE PENELITIAN}

Berdasarkan rumusan masalah dan tujuan yang telah dijelaskan pada bab sebelumnya, maka penelitian ini tergolong penelitian asosiatif kausal (sebab-akibat), dimana penelitian assosiatif merupakan penelitian yang bertujuan untuk mengetahui hubungan antara dua variabel atau lebih (Sugiyono, 2016). Hubungan kausal merupakan hubungan yang bersifat sebab-akibat yaitu salah satu variabel (independen) mempengaruhi variabel lain (dependen). Selain itu, jenis penelitian ini adalah explanatory research. Explanatory research merupakan penelitian yang menjelaskan hubungan antara variabel-variabel penelitian dan pengujian hipotesis yang telah dirumuskan sebelumnya (Sugiyono, 2016). Penelitian ini berusaha menjelaskan pengaruh good corporate governance dan struktur kepemilikan terhadap profitabilitas perusahaan.

\section{Populasi dan Sampel}

Populasi dalam penelitian ini adalah perusahaan non keuangan sektor infrastruktur, utilitas, dan transportasi yang terdaftar di BEI periode 2017-2019. Berdasarkan data yang diperoleh dari website resmi bursa efek Indonesia (www.idx.co.id) terdapat 78 perusahaan sektor infrastruktur, utilitas, dan transportasi yang terdaftar di BEI periode 2017-2019. Kemudian, sampel yang digunakan oleh peneliti adalah sebanyak 34 perusahaan yang memenuhi kriteria yang sudah ditetapkan oleh peneliti.

\section{Jenis dan Sumber Data}

Jenis data yang digunakan dalam penelitian ini adalah data kuantitatif yang merupakan data berbentuk angka (Sugiyono, 2016). Data kuantitatif yang digunakan oleh peneliti yaitu berupa angka-angka yang dapat dihitung atau diukur menggunakan rumusrumus pengukuran variabel penelitian. Sumber data dalam penelitian ini adalah dara sekunder. Data sekunder diperoleh dari laporan tahunan (annual report) dan laporan keuangan (financial statement) perusahaan non keuangan sektor infrastruktur, utilitas, dan transportasi yang terdaftar di Bursa Efek Indonesia Periode 2017-2019. Selain dari website bursa efek Indonesia, data untuk penelitian ini juga diperoleh dari website masing-masing perusahaan yang akan diteliti.

\section{Metode Pengumpulan Data}

Metode pengumpulan data merupakan cara yang digunakan untuk memperoleh data penelitian. Pengumpulan data yang digunakan adalah studi dokumen dan dokumen yang digunakan pada penelitian ini adalah dokumen sekunder. Metode dokumen merupakan pengumpulan data yang diperoleh dari dokumen terkait dengan laporan keuangan, laporan tahunan, dan ringkasan kinerja perusahaan non keuangan sektor infrastruktur yang terdaftar di Bursa Efek Indonesia Periode 2017-2019. Sedangkan metode studi pustaka merupakan pengumpulan data yang diperoleh dengan melakukan telaah pustaka, eksplorasi, dan mengkaji berbagai literatur pustaka, seperti buku, jurnal, artikel dan sumber lainnya yang terkait dengan penelitian ini.

\section{Metode Penentuan Sampel}

Metode penentuan sampel yang digunakan pada penelitian purposive sampling. purposive sampling yaitu teknik pengam,bilan sampel sumber data dengan pertimbangan tertentu (Sugiyono, 2016). Penentuan sampel yang digunakan pada penelitian ini adalah 
perusahaan yang mempublikasikan laporan tahunan serta data tentang good corporate governance dan struktur kepemilikan yang memuat tentang informasi dan ukuran dewan komisaris, dewan direksi, komite audit, kepemilikan manajerial, serta kepemilikan institusional pada tahun 2017-2019, perusahaan yang menyajikan laporan keuangan yang berakhir pada 31 Desember 2017, 31 Desember 2018, dan 31 Desember 2019 serta menyediakan data yang dibutuhkan untuk penelitian secara lengkap, perusahaan yang tidak delisting selama periode 2017-2019, dan perusahaan non keuangan sektor infrastruktur, utilitas, dan trasnportasi yang memperoleh laba positif atau perusahaan yang tidak mengalami kerugian selama tahun 2017 sampai dengan tahun 2019.

\section{Defenisi Operasional Variabel}

Defenisi operasional merupakan aspek penelitian yang memberikan informasi dalam mengukur suatu variabel.

a. Profitabilitas perusahaan diukur menggunakan ROE (Return on Equity). Hal ini dikarenakan investor dapat melihat seberapa besar perusahaan dapat menghasilkan return atas investasi yang sudah mereka tanamkan pada perusahaan. Besarnya laba yang dapat dihasilkan oleh perusahaan akan dapat mengukur tingkat profitabilitas. Dengan adanya pengukuran profitabilitas perusahaan tersebut, maka dapat ditinjau bagaimana proses pengambilan keputusan manajemen dalam mencapai tujuan perusahaan.

b. Dewan komisaris diukur dengan menggunakan jumlah anggota dewan komisaris pada suatu perusahaan.

c. Dewan direksi diukur dengan menggunakan jumlah anggota dewan direksi pada suatu perusahaan.

d. Komite audit diukur menggunakan perbandingan antara jumlah seluruh anggota komite audit dalam perusahaan.

e. Kepemilikan manajerial merupakan persentase dari perbandingan antara kepemilikan saham oleh manajemen dengan total saham beredar.

f. Kepemilikan institusional merupakan kepemilikan yang mempunyai pengaruh dalam perusahaan untuk memonitoring kerja dari seorang manajer pada suatu perusahaan. Kepemilikan institusional diukur menggunakan persentase proporsi kepemilikan institusional dalam struktur kepemilikan saham perusahaan.

\section{HASIL DAN PEMBAHASAN}

Berdasarkan data yang diperoleh dari BEI melalui website resminya www.idx.co.id . diketahui bahwa populasi penelitian ini berjumlah 78 perusahaan. Pemilihan sampel pada penelitian ini menggunakan metode purposive sampling yaitu pemilihan sampel dengan menggunakan pertimbangan atau kriteria tertentu. Adapun kriteria yang digunakan adalah sebagai berikut :

Tabel 2

Sampel Penelitian

\begin{tabular}{clc}
\hline No & \multicolumn{1}{c}{ Kriteria Pemilihan Sampel } & Jumlah \\
\hline 1 & $\begin{array}{l}\text { Perusahaan sektor infrastruktur, utilitas, dam transportasi } \\
\text { yang terdaftar di BEI periode 2017-2019 }\end{array}$ & 78 \\
2 & $\begin{array}{l}\text { Perusahaan sektor infrastruktur, utilitas, dan transportasi } \\
\text { yang delisting antara tahun 2017 atau 2018 atau 2019 }\end{array}$ & $(2)$ \\
3 & $\begin{array}{l}\text { Perusahaan yang tidak mempublikasikan laporan } \\
\text { keuangan secara lengkap pada tahun 2017-2019 }\end{array}$ & $(42)$ \\
4 & Perusahaan yang menjadi sampel & 34 \\
\hline Sumber $:$ & www.idx.co.id
\end{tabular}


Berdasarkan daftar nama perusahaan dan data profitabilitas, dewan komisaris, dewan direksi, komite audit, kepemilikan manajerial, dan kepemilikan institusional yang diolah menggunakan program spss maka diperoleh hasil statisitik deskriptif sebagai berikut :

Tabel 3

Hasil Analisis Statistik Deskriptif

\begin{tabular}{|c|c|c|c|c|c|}
\hline & $\mathbf{N}$ & Minimun & Maximum & Mean & Std. Deviation \\
\hline ROE & $\begin{array}{c}102 \\
(34 \text { perusahaan } \\
\text { tahun })\end{array}$ & $-0,6347$ & 0,7344 & 0,109275 & 0,1427522 \\
\hline Dewan Komisaris & $\begin{array}{c}102 \\
(34 \text { perusahaan } \\
\text { tahun) }\end{array} \times 3$ & 1 & 9 & 3,49 & 1,699 \\
\hline Dewan Direksi & $\begin{array}{c}102 \\
(34 \text { perusahaan } \\
\text { tahun })\end{array}$ & 2 & 9 & 4,02 & 1,515 \\
\hline Komite Audit & $\begin{array}{c}102 \\
\text { (34 perusahaan } \\
\text { tahun })\end{array}$ & 2 & 7 & 3,07 & 0,618 \\
\hline $\begin{array}{l}\text { Kepemilikan } \\
\text { Manajerial }\end{array}$ & $\begin{array}{c}102 \\
(34 \text { perusahaan } \\
\text { tahun })\end{array}$ & 0,0000 & 0,8047 & 0,058792 & 0,1420506 \\
\hline $\begin{array}{l}\text { Kepemilikan } \\
\text { Institusional }\end{array}$ & $\begin{array}{c}\text { (34 perusahaan } \\
\text { tahun) }\end{array}$ & 0,0315 & 1,0000 & 1,588004 & 0,2732611 \\
\hline Valid N (listwise) & 102 & & & & \\
\hline
\end{tabular}

Sumber : data sekunder yang diolah

Berdasarkan Tabel 3, dapat diketahui bahwa Return on equity (ROE) berkisar antara 0,6347 dan 0,7344 dengan nilai rata-rata sebesar 0,109275 dan standar deviasi sebesar 0,1427522 . Perusahaan dengan ROE terendah adalah PT Guna Timur Raya Tbk pada tahun 2019 yakni sebesar -0,6347 sedangkan ROE tertinggi diraih oleh PT Tower Bersama Infrastructure Tbk pada tahun 2017 dengan nilai ROE 0,7344.

Besarnya proporsi dewan komisaris berkisar antara 1 dan 9 dengan nilai rata-rata sebesar 3,49 dan standar deviasi sebesar 1,699. Perusahaan yang mempunyai nilai proporsi dewan komisaris terendah adalah Transcoal Pasific Tbk dan Gihon Telekomunikasi Indonesia Tbk masing-masing sebesar 1 pada tahun 2017, sedangkan perusahaan yang mempunyai proporsi dewan komisaris tertinggi adalah Cikarang Listrindo Tbk yakni sebesar 9 pada 3 tahun berturut-turut yaitu 2017, 2018, 2019.

Proporsi dewan direksi berkisar antara 2 dan 9 dengan nilai rata-rata 4,02 dan standar deviasi sebesar 1,515. Terdapat beberapa perusahaan yang memiliki proporsi dewan direksi terendah yaitu Sillo Maritime Perdana Tbk tahun 2017, Gihon Telekomunikasi Indonesia Tbk tahun 2017, Batavia Prosperindo Trans Tbk tahun 2017, 2018, 2019, Guna Timur Raya Tbk tahun 2017, 2018, 2019, Jaya Trishindo Tbk tahun 2017, 2018, 2019, Humpuss Intermoda Transportasi Tbk tahun 2017, 2018, 2019, Jasa Armada Indonesia Tbk tahun 2018, masingmasing sebesar 2. Sedangkan perusahaan yang mempunyai proporsi dewan direksi tertinggi adalah Telekomunikasi Indonesia (Persero) Tbk pada tahun 2018 dan 2019 yakni sebesar 9.

Proporsi komite audit berkisar antara 2 dan 7 dengan nilai rata-rata 3,07 dan standar deviasi 0,618. Perusahaan dengan proporsi komite audit terendah adalah Buana Lintas Lautan Tbk tahun 2017, 2018, 2019, sedangkan perusahaan yang mempunyai proporsi komite audit tertinggi adalah Telekomunikasi Indonesia (Persero) Tbk pada tahun 2017.

Kepemilikan manajerial perusahaan berkisar antara 0,0000 dan 0,8047 dengan nilai rata-rata 0,058792 dan standar deviasi 0,1420506 . Perusahaan yang mempunyai kepemilikan 
manajerial terendah adalah Rukun Raharja Tbk tahun 2017, 2018, 2019, Telekomunikasi Indonesia (Persero) Tbk tahun 2019, Jaya Trishindo Tbk tahun 2018, Jasa Armada Indonesia Tbk tahun 2017, 2018, 2019, illo Maritime Perdana Tbk tahun 2017, 2018, 2019, Transcoal Pasific Tbk tahun 2017, 2018, 2019, Bali Towerindo Sentra Tbk yahun 2017, 2018, 2019, Inti Bangun Sejahtera Tbk tahun 2017, 2018, 2019, LCK Global Kedaton Tbk tahun 2018, 2019, Citra Marga Nusaphala Persada Tbk tahun 2017, Nusantara Infrastructure Tbk tahun 2017, 2018, 2019, dan Trimuda Nuansa Citra Tbk tahun 2017, 2018, 2019. Sedangkan perusahaan dengan kepemilikan manajerial tertinggi adalah Jaya Trishindo Tbk pada tahun 2017.

Kepemilikan institusional perusahaan berkisar antara 0,0315 dan 1,0000 dengan nilai rata-rata 1,588004 dan standar deviasi 0,2732611. Perusahaan dengan kepemilikan institusional terendah yaitu Jasa Marga (Persero) Tbk pada tahun 2017, sedangkan perusahaan yang memiliki kepemilikan institusional tertinggi adalah Jaya Trishindo Tbk tahun 2017 dan Transcoal Pasifik Tbk tahun 2017.

Tabel 4

Hasil Analisis Regresi Linear Berganda

\begin{tabular}{lrrrrr}
\hline & \multicolumn{2}{c}{$\begin{array}{c}\text { Unstandardized } \\
\text { Coefficients } \\
\text { Std. Error }\end{array}$} & $\begin{array}{c}\text { Standardized } \\
\text { Coefficients } \\
\text { Beta }\end{array}$ & t & Sig. \\
\hline (Constant) & $-0,164$ & 0,087 & & -1.880 & 0,063 \\
Dewan Komisaris & $-0,014$ & 0,010 & $-0,172$ & $-1,514$ & 0,133 \\
Dewan Direksi & 0,027 & 0,012 & 0,286 & 2,344 & 0,021 \\
Komite Audit & 0,053 & 0,025 & 0,228 & 2,071 & 0,041 \\
Kepemilikan Manajerial & 0,142 & 0,099 & 0,142 & 1,432 & 0,155 \\
Kepemilikan & 0,077 & 0,055 & 0,148 & 1,408 & 0,162 \\
Institusional & & & & & \\
\hline
\end{tabular}

Sumber : data yang diolah

Dari hasil perhitungan analisis regresi linear berganda pada Tabel 4, maka dapat dibuat persamaan regresi berikut :

$$
\mathrm{Y}=-0,164-0,014 \mathrm{DK}+0,027 \mathrm{DD}+0,053 \mathrm{KA}+0,142 \mathrm{KMAN}+0,077 \mathrm{KINST}+\mathrm{e}
$$

Berdasarkan persamaan diatas, maka dapat disimpulkan bahwa :

1) Nilai konstanta dari persamaan regresi diatas adalah sebesar -0,164, artinya dewan komisaris (X1), dewan direksi (X2), komite audit (X3), kepemilikan manajerial (X4), kepemilikan institusional (X5) nilainya diasumsikan tetap, maka profitabilitas (Y) adalah sebesar 0,164.

2) Koefisien regresi variabel dewan komisaris sebesar -0,014, dapat disimpulkan bahwa jika variabel independen lain nilainya tetap dan dewan komisaris mengalami kenaikan satu poin, maka akan diikuti dengan penurunan profitabilitas sebesar 0,014 .

3) Variabel dewan direksi mempunyai koefisien regresi sebesar 0,027, dapat disimpulkan bahwa jika variabel independen lain nilainya tetap dan dewan direksi mengalami kenaikan satu poin, maka akan diikuti dengan penurunan profitabilitas sebesar 0,027.

4) Koefisien regresi variabel komite audit sebesar 0,053, dapat disimpulkan bahwa jika variabel lain nilainya tetap dan jumlah komite audit mengalami kenaikan satu poin, maka akan diikuti dengan kenaikan profitabilitas sebesar 0,053.

5) Variabel kepemilikan manajerial mempunyai koefisien regresi sebesar 0,142 , dapat disimpulkan bahwa jika variabel independen lain nilainya tetap dan jumlah 
kepemilikan manajerial mengalami kenaikan satu poin, maka akan diikuti dengan kenaikan profitabilitas sebesar 0,142 .

6) Koefisien regresi variabel kepemilikan institusional sebesar 0,077, dapat disimpulkan bahwa jika variabel independen lain nilainya tetap dan kepemilikan institusional mengalamai kenaikan satu poin, maka akan diikuti dengan kenaikan profitabilitas sebesar 0,077 .

Berdasarkan analisis uji t pada Tabel 4 diketahui bahwa nilai $-1,98472<-1,514<$ 1,98472 dengan tingkat signifikan $0,133>0,05$, maka dapat disimpulkan bahwa Ho diterima dan Ha ditolak, artinya dewan komisaris tidak berpengaruh terhadap profitabilitas perusahaan. Berdasarkan analisis uji $t$ diketahui bahwa nilai $t>1,98472$, yaitu 2,344 $>1,98472$ dengan tingkat signifikan 0,021<0,05, maka dapat disimpulkan bahwa Ho ditolak dan Ha diterima, artinya dewan direksi berpengaruh signifikan terhadap profitabilitas perusahaan. Berdasarkan analisis uji $\mathrm{t}$ diketahui bahwa nilai $\mathrm{t}>1,98472$ yaitu $2,071>1,98472$ dengan tingkat signifikan $0,041<0,05$, maka dapat disimpulkan bahwa Ho ditolak dan Ha diterima, artinya komite audit berpengaruh signifikan terhadap profitabilitas perusahaan.

Berdasarkan analisis uji t diketahui bahwa nilai $\mathrm{t}<1,98472$ yaitu $1,432>1,98472$ dengan tingkat signifikan $0,155>0,05$, maka dapat disimpulkan bahwa Ho diterima dan Ha ditolak, artinya kepemilikan manajerial tidak berpengaruh terhadap profitabilitas perusahaan. Berdasarkan analisis uji t diketahui bahwa nilai t yaitu $-1,98472<1,408<1,98472$ dengan tingkat signifikan 0,162 >0,05, maka dapat disimpulkan bahwa Ho diterima dan Ha ditolak, artinya kepemilikan institusional tidak berpengaruh signifikan terhadap profitabilitas perusahaan.

\section{Tabel 5}

Hasil Uji F

\begin{tabular}{|c|c|c|c|c|c|c|}
\hline & Model & Sum of Squares & Df & $\begin{array}{c}\text { Mean } \\
\text { Square }\end{array}$ & $\mathbf{F}$ & Sig. \\
\hline & Regression & 0,279 & 5 & 0,56 & 3,012 & $0,014^{\mathrm{b}}$ \\
\hline 1 & Residual & 1,779 & 96 & 0,019 & & \\
\hline & Total & 2,058 & 101 & & & \\
\hline
\end{tabular}

Berdasarkan hasil uji F, maka didapatkan hasil bahwa $F_{\text {hitung }}>F_{\text {tabel }}$ yaitu 3,012 $>2,47$ dengan tingkat signifikansi $0,014<0,05$. Oleh karena itu dapat disimpulkan bahwa Ho ditolak dan Ha diterima, aritinya dewan komisaris, dewan direksi, komite audit, kepemilikan manajerial, dan kepemilkan institusional secara simultan berpengaruh signifikan terhadap profitabilitas perusahaan.

Tabel 6

Hasil Uji Koefisien Determinasi $\left(\mathbf{R}^{2}\right)$

\begin{tabular}{lrrrr} 
Model & R & R Square & Adjusted R Square & $\begin{array}{c}\text { Std. Error of the } \\
\text { Estimate }\end{array}$ \\
1 & $0,368^{\mathrm{a}}$ & 0,136 & 0,091 & 0,1361346 \\
\hline Sumber : data yang diolah & & &
\end{tabular}

Berdasarkan Tabel 6 diatas dapat dilihat bahwa nilai Adjusted $\mathrm{R}$ square $\left(\mathrm{R}^{2)}\right.$ sebesar 0,091. Nilai ini menunjukkan bahwa profitabilitas perusahaan dipengaruhi oleh $9,1 \%$ variabel dewan komisaris, dewan direksi, komite audit, kepemilikan manajerial, dan kepemilikan 
institusional, sedangkan sisanya sebesar 90,9\% dipengaruhi oleh variabel lain diluar variabel yang digunakan dalam penelitian ini.

\section{Pengaruh dewan komisaris terhadap profitabilitas perusahaan}

Hasil penelitian ini menunjukkan bahwa variabel dewan komisaris berpengaruh negatif dan tidak signifikan terhadap profitabilitas perusahaan. Hal ini dapat dilihat dari koefisien regresi yang bernilai $-0,014$ dan nilai $t_{\text {hitung }}$ lebih kecil dari $t_{\text {tabel }}$ yaitu $-1,514<$ 1,98472 dengan tingkat signifikan $0,133>0,05$, maka dari itu Ho diterima dan Ha ditolak. Hasil ini menunjukkan hipotesis yang menyatakan bahwa dewan komisaris berpengaruh negatif dan tidak signifikan terhadap profitabilitas perusahaan. Seluruh perusahaan pada sampel penelitian ini telah memenuhi ketentuan BEI bahwa peryaratan jumlah dewan komisaris tidak melebihi jumlah dewan direksi.

Nilai koefisien regresi yang sebesar -0,014 menunjukkan bahwa setiap kenaikan satu poin dewan komisaris akan menurunkan nilai profitabilitas perusahaan sebesar 0,014 . Hal inilah yang menjadi penyebab adanya hubungan negatif dewan komisaris terhadap profitabilitas perusahaan. Sehingga hipotesis yang diajukan terbukti bahwa dewan komisaris berpengaruh negatif dan tidak signifikan terhadap profitabilitas perusahaan. Dewan Komisaris sebagai mekanisme pengendalian internal tertinggi yang bertanggung jawab secara kolektif untuk melakukan pengawasan dan memberi masukan kepada direksi serta memastikan bahwa perusahaan melaksanakan good corporate governance. Dewan komisaris tidak mempunyai otoritas langsung terhadap perusahaan. Namun posisi dewan komisaris sangat penting dalam menjembatani kepentingan principal dalam sebuah perusahaan karena fungsi utama dewan komisaris adalah mengawasi kelengkapan dan kualitas informasi atas kinerja dewan direksi. Namun, dengan semakin banyaknya jumlah dewan komisaris suatu perusahaan maka akan menciptakan berbagai macam keputusan yang nantinya akan menimbulkan permasalahan dalam hal komunikasi dan koordinasi sehingga adanya kesulitan dalam melakukan pengawasan. Permasalahan yang ditimbulkan oleh semakin besarnya jumlah dewan komisaris ini akan mengakibatkan profitabilitas perusahaan menurun, hal itu disebabkan oleh munculnya pemisahan antara manajemen dan kontrol perusahaan. Selain itu, dewan komisaris independen banyak berasal dari berbagai latar belakang pendidikan dan pengalaman kerja yang tidak relevan dengan bidang usaha perusahaan.

\section{Pengaruh dewan direksi terhadap profitabilitas perusahaan}

Hasil penelitian ini menunjukkan bahwa variabel dewan direksi berpengaruh positif dan signifikan terhadap profitabilitas perusahaan. Hal ini dapat dilihat dari koefisien regresi yang bernilai 0,027 dan nilai t yaitu 2,344 > 1,98472 dengan tingkat signifikan 0,021<0,05, maka dapat disimpulkan bahwa Ho ditolak dan Ha diterima. Nilai koefisien regresi yang sebesar 0,027 menunjukkan bahwa setiap kenaikan satu poin dewan komisaris akan meningkatkan nilai profitabilitas perusahaan sebesar 0,027. Hal inilah yang menjadi penyebab adanya hubungan positif dewan direksi terhadap profitabilitas perusahaan. Sehingga hipotesis yang diajukan terbukti bahwa dewan direksi berpengaruh positif dan signifikan terhadap profitabilitas perusahaan.

Dewan direksi adalah penerima nasihat dari dewan komisaris. Ketika dewan direksi melakukan kelalaian dan kesalahan dalam menjalankan tugasnya maka dewan direksi harus betanggung jawab secara penuh atas kerugian perusahaan. Peraturan tersebut disebutkan dalam Pasal 97 ayat (2) UUPT. Jadi, apabila jumlah anggota dewan direksi dalam sebuah perusahaan semakin banyak maka akan semakin banyak ahli yang memiliki kemampuan operasional dalam berbagai bidang dan divisi; sehingga visi, misi dan strategi perusahaan dapat dilaksanakan sesuai dengan rencana. 


\section{Pengaruh komite audit terhadap profitabilitas perusahaan}

Hasil penelitian ini menunjukkan bahwa variabel komite audit berpengaruh positif dan signifikan terhadap profitabilitas perusahaan. Hal ini dapat dilihat dari koefisien regresi yang bernilai 0,053 dan nilai t yaitu 2,071 > 1,98472 dengan tingkat signifikan 0,041<0,05, maka dapat disimpulkan bahwa Ho ditolak dan Ha diterima. Nilai koefisien regresi yang sebesar 0,053 menunjukkan bahwa setiap kenaikan satu poin komite audit akan meningkatkan nilai profitabilitas perusahaan sebesar 0,053 . Hal inilah yang menjadi penyebab adanya hubungan positif komite audit terhadap profitabilitas perusahaan. Sehingga hipotesis yang diajukan terbukti bahwa komite audit berpengaruh positif dan signifikan terhadap profitabilitas perusahaan.

Pemerintah telah menetapkan aturan melalui Keputusan Bapepam nomor Kep643/BL/2012 yang menyatakan bahwa komite audit terdiri dari sekurang-kurangnya satu komisaris independen yang bertindak sebagai ketua komite audit dan sekurang-kurangnya dua orang anggota lain yang berasala dari luar perusahaan publik. Komite audit memiliki peran dalam membantu dewan komisaris dalam mengawasi kegiatan perusahaan, khususnya dalam pengawasan pengendalian internal perusahaan. Komite audit juga berperan untuk menjembatani antara auditor eksternal dan auditor internal. Dengan pengawasan yang dilakukan oleh komite audit terhadap pengendalian internal perusahaan, maka akan memperkecil terjadinya tindakan tidak sehat yang dilakukan oleh manajemen demi kepentingannya sendiri. Jadi, semakin banyak komposisi komite audit maka kinerja keuangan akan terawasi dengan baik sehingga kinerja akan meningkat.

\section{Pengaruh kepemilikan manajerial terhadap profitabilitas perusahaan}

Hasil penelitian ini menunjukkan bahwa variabel kepemilikan manajerial berpengaruh positif dan tidak signifikan terhadap profitabilitas perusahaan. Hal ini dapat dilihat dari koefisien regresi yang bernilai 0,142 dan nilai t yaitu $1,432<1,98472$ dengan tingkat signifikan 0,155 >0,05, maka dapat disimpulkan bahwa Ho diterima dan Ha ditolak. Nilai koefisien regresi yang sebesar 0,142 menunjukkan bahwa setiap kenaikan satu poin kepemilkan manajerial akan meningkatkan nilai profitabilitas perusahaan sebesar 0,142 . Hal inilah yang menjadi penyebab adanya hubungan positif kepemilkan manajerial terhadap profitabilitas perusahaan. Sehingga hipotesis yang diajukan terbukti bahwa kepemilkan manajerial berpengaruh positif dan tidak signifikan terhadap profitabilitas perusahaan.

Hal ini disebabkan oleh rendahnya tingkat kepemilikan manajerial pada perusahaan sektor infrastruktur, utilitas, dan transportasi ini sehingga menyebabkan beberapa perusahaan selama periode penelitian tidak memberikan kepemilikan sahamnya kepada manajemen. Kepemilikan manajerial pada level yang rendah menyebabkan manajer kurang maksimal dalam menjalankan tugasnya untuk memaksimalkan kekayaan pemegang saham serta berusaha mengalihkan sumber daya perusahaan untuk kepentingan mereka sendiri. Hal ini dikarenakan, manajer tidak seutuhnya mendapat keuntungan yang diperoleh, tetapi mereka juga menanggung biaya yang dikeluarkan untuk meningkatkan keuntungan perusahaan. Dan jika kepemilikan manajerial yang dimiliki semakin besar, maka manajemen akan berusaha memaksimalkan kekayaan pemegang saham.

\section{Pengaruh kepemilikan institusional terhadap profitabilitas perusahaan}

Hasil penelitian ini menunjukkan bahwa variabel kepemilikan institusional berpengaruh positif dan tidak signifikan terhadap profitabilitas perusahaan. Hal ini dapat dilihat dari koefisien regresi yang bernilai 0,077 dan nilai t yaitu 1,408 $<1,98472$ dengan tingkat signifikan 0,162>0,05, maka dapat disimpulkan bahwa Ho ditolak dan Ha diterima. Nilai koefisien regresi yang sebesar 0,077 menunjukkan bahwa setiap kenaikan satu poin kepemilkan institusional akan meningkatkan nilai profitabilitas perusahaan sebesar 0,077 . 
Hal inilah yang menjadi penyebab adanya hubungan positif kepemilkan institusional terhadap profitabilitas perusahaan. Sehingga hipotesis yang diajukan terbukti bahwa kepemilkan institusional berpengaruh positif dan tidak signifikan terhadap profitabilitas perusahaan.

Hal ini disebabkan oleh pemilik mayoritas institusi juga ikut dalam pengendalian kepentigan mereka sendiri meskipun dengan mengorbankan kepentingan pemilik minoritas. Adanya asimetri informasi antara oemegang saham dengan manajer menyebabkan manajer selaku pengelola perusahaan akan bisa mengendalikan perusahaan karena memiliki informasi lebih mengenai perusahaan dibandingkan pemegang saham. Sehingga adanya kepemilikan institusi tidak menjamin monitoring kinerja manajer berjalan efektif.

\section{SIMPULAN, KETERBATASAN DAN SARAN Simpulan}

Dari hasil pengolahan data dan pembahasan dari hasil penelitian antara variabel independen terhadap variabel variabel dependen yang telah diuraikan, maka dapat disimpulkan sebagai berikut: (1) Dewan komisaris berpengaruh negatif dan tidak signifikan terhadap profitabilitas perusahaan. (2) Dewan direksi berpengaruh positif dan signifikan terhadap profitabilitas perusahaan. (3) Komite audit berpengaruh positif dan signifikan terhadap profitabilitas perusahaan. (4) Kepemilikan manajerial berpengaruh positif dan signifikan terhadap profitabilitas perusahaan. (5) Kepemilikan institusional berpengaruh positif dan tidak signifikan terhadap profitabilitas perusahaan. (6) Dewan komisaris, dewan direksi, komite audit, kepemiilkan manajerial, dan kepemilkan institusional berpengaruh signifikan terhadap profitabilitas perusahaan.

\section{Keterbatasan}

Terdapat beberapa keterbatasan dalam penelitian ini meskipun peneliti telah berusaha mengembangkan penelitian ini sedemikian rupa. Adapun keterbatasannya adalah sebagai berikut: (1) Adanya perusahaan non keuangan sektor infrastruktur, utilitas, dan transportasi yang dijadikan sampel pada penelitian ini tidak menyampaikan laporan tahunan secara lengkap sehingga sulitnya memperoleh data-data yang dibutuhkan untuk diteliti. (2) Proksi yang digunakan untuk mengukur profitabilitas perusahaan hanya menggunakan ROE sehingga profitabilitas perusahaan pada penelitian ini hanya dilihat dari satu sudut pandang saja.

\section{Saran}

Beberapa saran yang dapat peneliti sampaikan berdasarkan analisis yang telah dilakukan adalah sebagai berikut: (1) Perusahaan hendaknya mampu mempertahankan dan meningkatkan kinerjanya. Peningkatan kinerja ini dapat dilakukan dengan menerapkan good corporate governance dengan baik dan benar. Suatu perusahaan harus memiliki dewan komisaris, dewan direksi, dan komite audit secara selektif karena posisi tersebut sangat diperlukan dan juga posisi ini menentukan keberhasilan dan peningkatan kinerja perusahaan. (2) Perusahaan sektor infrastruktur, utilitas, dan transportasi disarankan untuk meningkatkan ukuran dewan direksi perusahaan, karena semakin banyak jumlah anggota dewan direksi maka semakin banyak ahli yang memiliki kemampuan operasional dalam berbagai bidang dan divisi sehingga visi, misi dan strategi perusahaan dapat dilaksanakan sesuai dengan rencana. (3) Perusahaan sektor infrastruktur, utilitas, dan transportasi disarankan untuk meningkatkan ukuran komite audit perusahaan, karena dengan pengawasan yang dilakukan oleh komite audit terhadap pengendalian internal perusahaan, akan memperkecil terjadinya tindakan tidak sehat yang dilakukan oleh manajemen demi kepentingannya sendiri. (4) Bagi para peneliti selanjutnya disarankan dapat menambah jumlah sampel yang digunakan agar hasil yang didapatkan juga lebih banyak dan lebih akurat sehingga dapat mewakili dari 
populasi penelitian. Selain itu, disarankan melakukan penambahan atau perubahan variabel penelitian yang digunakan untuk menemukan variabel-variabel lain yang lebih memiliki pengaruh terhadap profitabilitas perusahaan.

\section{DAFTAR PUSTAKA}

Effendi, M. A. (2009). The Power of Corporate Governance. Salemba Empat.

Ghozali, I. (2018). Aplikasi Analisis Multivariate dengan Program IBM SPSS 25. Badan Penerbit Universitas Diponegoro.

Hantono, . . (2018). Faktor Yang Mempengaruhi Profitabilitas Pada Perusahaan Property Dan Real Estate Yang Terdaftar Di Bei Periode 2012-2015 Hantono. JMBI UNSRAT (Jurnal Ilmiah Manajemen Bisnis Dan Inovasi Universitas Sam Ratulangi)., 5(1), 1-14. https://doi.org/10.35794/jmbi.v5i1.19147

Kasmir. (2014). Analisis Laporan Keuangan. PT Raja Grafindo Persada.

Masdupi, E. (2005). Analisis Dampak Struktur Kepemilikan pada Kebijakan Hutang dalam Mengontrol Konflik Keagenan. Ekonomi Dan Bisnis Indonesia, 20(1), 57-69.

Muhammad, F. (2008). Reivening Local Government: Pengamalan dari Daerah. PT Elex Media Komputindo.

Munawir, S. (2004). Analisis Laporan Keuangan. Liberty.

Priatna, H. (2016). Pengukuran Kinerja Perusahaan Dengan Rasio Profitabilitas. Jurnal Ilmiah Akuntansi, 7(2), 44-53. http://ejournal.unibba.ac.id/index.php/AKURAT

Saeno. (2019). Rini Soemarno Beberkan Kontribusi BUMN Bangun Infrastruktur Tanah Air. Bisnis.Com. https://ekonomi.bisnis.com/read/20190716/45/1125026/rini-soemarnobeberkan-kontribusi-bumn-bangun-infrastruktur-tanah-air

Sembiring, E. G. (2017). Pengaruh Penerapan Good Corporate Governance Dan Struktur. Jom FISIP, 4(2), 1-18.

Sudana, I. M. (2011). Manajemen Keuangan Perusahaan Teori dan Praktik. Erlangga.

Sugiyono. (2014). Metode Penelitian Pendidikan Pendekatan Kuantitatif, Kualitatif, dan $R \& D$. Alfabeta.

Sugiyono. (2016). Metode Penelitian Kuantitatif, Kualitatif, dan R\&D. Alfabeta.

Tjeleni, I. E. (2013). Kepemilikan Manajerial Dan Institusional Pengaruhnya Terhadap Kebijakan Hutang Pada Perusahaan Manufaktur Di Bursa Efek Indonesia. EMBA, 1(3), 129-139. 